Оксана ПАЛІй

\title{
ДІЯЛЬНІСТЬ ТЕАТРУ ІМЕНІ МАРІЇ ЗАНЬКОВЕЦЬКОЇ ПЕРЕХІДНОГО ПЕРІОДУ (1925-1926 рр.)
}

У статті розглянуто діяльність театру імені Марії Заньковещької після смерті Олександра Корольчука у Запоріжжі (1925 р.), але перед приходом Олександра Загарова. Йдеться про так званий «темний», або перехідний, період, після якого радянська влада призначила «згори» Олександра Загарова. Відтак період діяльності театру між О. Корольчуком і О. Загаровим, справді є наймени вивченим.

Ключові слова: Олександр Корольчук, Олександр Загаров, Борис Романицький, Панас Саксганський, Вільям Шекспір, театр імені Марії Заньковеиької, драматургія, сиена.

В статье рассмотрена тема деятельности театра имени Марии Заньковеикой после смерти Александра Корольчука (1925 г.) и перед приходом Александра Загарова. Речь идет о так называемом «темном», или переходном, периоде, после которого, советская власть назначила художественным руководителем Александра Загарова. Соответственно, период деятельности театра между двумя худруками А. Корольчуком и А. Загаровым наимение изучен.

Ключевые слова: Александр Корольчук, Александр Загаров, Борис Романицкий, Панас Саксаганский, Уильям Шекспир, театр имени Марии Заньковецкой, драматургия, сцена.

The article deals with the activities of the theater named after Maria Zankovetska after the death of Alexander Korolchuk in Zaporozhye (1925), but before the arrival of Alexander Zaharov. This is about the socalled «dark» or transitional period, after which the Soviet government appointed "from above» by Alexander Zaharov. The refore, the period of the theater between $O$. Korolchuk and $O$. Zaharov is indeed the least learned.

Key words: Alexander Korolchuk, Alexander Zaharov, Boris Romanytskyi, Panas Sackshanskyi, William Shakespeare, Maria Zankovetska Theater, drama, stage.

Як відомо, свого мистецького керівника Олександра Корольчука заньківчани поховали у Запоріжжі. Згодом В. Яременко лаконічно зазначив у своїх спогадах: «3 березня (тобто 1925 р. - О. П.) заньківчани поховали там одного 3 найактивніших своїх фундаторів - Олександра Корольчука. То була значна втрата для театру» $[1,30]$. При цьому гастролі у Запоріжжі тривали до 6-го березня. Припускаємо, що головною причиною цього стало те, що згідно з наказом на удержавлення театр імені Марії Заньковецької мав забов'язання здійснювати так зване культурне обслуговування не лише Катеринослава, а й території всієї губернії [2, арк. 24].

По поверненні до Катеринослава у театрі імені Марії Заньковецької відбулася реорганізація колективу: так Борис Романицький перебрав на себе функції голови Ради театру, а Максим Лебідь водночас із посадою директора обійняв посаду уповноваженого колективу. Одним із перших документів колективу, виданих вже новим керівним складом, було звернення зі словами подяки громадськості, від якої надходила численна кількість листів та телеграм до колективу зі словами щирого співчуття. Звернення було надруковане на сторінках харківської газети «Вісті ВУЦВК»: «Держдрам театр ім. Заньковецької висловлює свою глибоку подяку всім установам, організаціям та поодиноким товаришам відчувшим нашу тяжку втрату - смерть Олександра Івановича Корольчука. Удари гартують. Ми не схибимо, не зійдемо зі свого шляху. Голова Ради театру ім. Заньковецької Борис Романицький та Уповноважений театру Максим Лебідь» $[3,6]$.

Як довідуємося із повідомлень запорізького оглядача газети «Красное Запорожье» під криптонімом «А»: «26 і 27 марта в Запорожье из Катеринослава приезжает одна из лучших украинских 
труп - театр имени Марии Заньковецкой. Репертуар этой труппы не только чисто украинский, а будут также представления по произведеньям мировой драмы, переведенным на украинский язык. Месяц трупа будет играть в театре имени Ленина, а после этого уедет в районы. Запорожская публика не должна оставаться глухой к лучшим драматическим силам на Украине» $[4,2]$.

Отже, можемо припускати, що вже наприкінці 1925 р. заньківчанська трупа знову відновила свої гастролі за раніше складеним маршрутом виступів. І по суті розпочала їх знову в Запоріжжі. У рамках цих гастролей колектив відвідав не лише Запоріжжя та його райони (передовсім Оріхів і Гуляй-поле), а й Павлоград, Мелітополь, Кривий Ріг. Маршрут цих гастролей, а також репертуар, що його колектив презентував місцевій публіці у згадуваних населених пунктах, укладав ще тогочасний керівник колективу Олександр Іванович Корольчук.

На нашу думку, слід зазначити, що під час організації маршруту гастролей були внесені певні корективи, котрі не зазначалися у публікаціях та спогадах занькічан про історію колективу цього періоду [5, 240-241]. Тому ми, спираючись, на архівні документи, спробуємо уточнити вже наявну інформацію про маршрут та тривалість цих гастрольних виступів. Адже із листування Олександра Корольчука довідуємося, що ще в грудні 1924 р. через організаційні труднощі було відмінено виступи у Кременчуці. Як зазначав у своєму листі сам О. Корольчук: «Я все-таки певен, що наші постановки в Кременчуці своє взяли б, але ми проситься не будемо, бо нас вже зараз підвели. Нам не цікавий Кременчук <..> У нас $є$ що показать, до нас підуть залюбки, є чим розворушить, полонить. В кінці-кінців нам пощастило нас удержавили, а це Вам не фунт ізюму» [6, арк. 2]. Вочевидь, на етапі перемовин про гастролі в Кременчуці не вдалося домовитися про прийнятні для колективу умови виступів, відтак Кременчук випав із гастрольного маршруту заньківчан ще в грудні 1924 р. Відтак у наявну інформацію про виступи заньківчан у Кременчуці в 1925 р., на нашу думку, слід внести корективи: гастролі колективу в цей час не відбулися [5, 240-241].

Також у фондовій збірці Музею театрального, музичного і кіномистецтва України (Київ) збереглася чернетка службової записки О. Корольчука до відділу мистецтв при Миколаївській окрінспектурі при Наросвіті. У цьому документі, тогочасний керманич колективу Олександр Корольчук закликав місцеву владу посприяти колективові під час гастролей у отриманні податкових пільг на електрику та оренду приміщення [7, арк. 1-3]. Напевно, реакція місцевих чиновників на запит O. I. Корольчука була позитивною, адже вже незабаром до митця надійшов лист від Миколаївського відділення спілки Робмис, в якому було прохання уточнити можливу дату прибуття на гастролі та репертуар [8, арк. 1].

А вже згодом заньківчани отримали так зване письмове посвідчення № 1542 від Миколаївського районного відділення Всеросійського відділення союзу металістів. Із цього документа довідуємося, що заньківчанський колектив впродовж липня виступав на сцені клубу при Державному суднобудівельному заводі імені Марті і Бадена. За цей час було продемонстровано 30 спектаклів, які, попри гідний рівень артистів-виконавців все-таки не здобули широкий резонанс серед місцевих глядачів, незважаючи на гнучку систему пільг при оплаті квитків [9, арк. 4]. Відтак чітко простежуємо, що так анонсовані широкомасштабні гастролі передовсім були покликані покращити матеріальний стан колективу. Насичений маршрут та динаміку цих гастрольних виступів у важких матеріальних умовах наголошував у своїх спогадах і В. Яременко $[1,30]$. Показова деталь: 17 листопада 1925 р. до театру імені Марії Заньковецької надійшла пропозиція про виступ із виставою трупи (назва спектаклю не вказана - О. П.) від політвідділу 15-ї дивізії Червоної Армії, за підписом заступника командира цієї дивізії - Ізельсона [10, арк. 5]. Тобто можемо припускати, що сезон 1924-1925 pp. колектив закінчив на гастролях у Миколаєві в серпні, а не в травні. Однак, як простежуємо із документів, із поодинокими виставами колектив виїздив на запрошення тієї чи іншої організації чи промислового підприємства, громади того чи іншого населеного пункту на Катеринославщині тощо. Відтак можемо уточнити і розширити інформацію, наведену у статті М. Лебідя [11, 29-30]. У цій публікації директор театру зазначив, що заньківчани закінчують сезон 17 травня в Катеринославі, оскільки мистецький керівник трупи Б. Романицький їде на виставку в Париж [12], а після цієї перерви, з 10 липня, колектив почне гастрольні виступи на Криворіжжі $[11,29]$. Однак із цитованих вище документів фондової збірки Центрального державного архіву вищих органів влади та управління України (Київ), ми довідуємося, що заньківчани насправді закінчили сезон наприкінці серпня у Миколаєві.

Опосередковано інформацію про літні гастролі у Миколаєві також підтверджують і самі 
Б. Романицький і В. Яременко у своїй замітці в місцевій пресі майже через півстоліття: «Ми висловлюємо глибоку вдячність миколаївцям, які стояли біля колиски нашого творчого розквіту. $<$.. > Наш колектив вперше побував на гастролях у Миколаєві ще 1924 р., а потім 1925 р. і 1927 р. ми знову гастролювали у Вашому чудовому місті» $[13,2]$ Але через відсутність потрібної інформації у пресі ми не маємо можливості реконструювати репертуар колективу під час цих гастролей. Відтак таке широке цитування згадуваних документів для нас важливе як джерело, з якого можемо уточнити, а іноді наново вписати окремі сторінки про історію функціонування колективу в цей час.

Так чи інакше театр імені Марії Заньковецької не раніше вересня 1925 р. повернувся до Катеринослава, де розпочалася активна фаза підготовки до сценічного першопрочитання «Отелло» В. Шекспіра у режисерській інтерпретації Панаса Саксаганського на українській сцені радянського періоду. Прем'єра цього спектаклю відбулась 6 лютого 1926 р. у Катеринославі [5, 240]. Принагідно слід зауважити, що у репертуарі ілюстрованого видання «Заньківчани», щодо хронології останнього видання, присвяченого історії театру імені Марії Заньковецької, помилково зазначено, що режисером-постановником спектаклю «Отелло» В. Шекспіра був Б. Романицький $[14,42]$. Окрім того, відомості про цю постановку ми можемо знайти практично у всіх книжках, присвячених історії заньківчан, зокрема у монографії Б. Кордіані та Л. Мельничук-Лучко [15], а також у книжці О. Кулика [16]. Також концепції основних акторських образів: Отелло - Борис Романицький [17]; Дездемона - Варвара Любарт [18]; Яго - Василь Яременко [19] посідають чільне місце у книжках, присвячених творчій біографії цих митців.

Однак у згадуваних працях ніде не знаходимо відомості про передумови створення цієї постановки, а також окремі аспекти творчої діяльності колективу у цей період свого функціонування. Так, скажімо, ми у жодній друкованій праці не бачимо інформації про те, що у «намітках репертуару», що їх складав тогочасний керманич колективу Олександр Корольчук як у сезоні 1923-1924pp. [20], так і в «намітках репертуару» сезону 1924 1925 pp. [21] у параграфі «план роботи колективу» твори В. Шекспіра посідали важливе місце. Причому перелік п’єс В. Шекспіра, котрі планував увести до репертуару заньківчан О. Корольчук у сезоні 1923-1924 рр., містив різножанрову драматургію: «Кумасі з Віндзору» та «Отелло», «Юлій Цезар» [20, арк. 1]. А ось вже у наступному сезоні
1924-1925 pр. О. І. Корольчук тепер дещо змінив у параграфі «план роботи» на 1924-1925 рр. у документі «Намітки репертуару»: «В плані роботи: "Гамлєт", “Отелло", “Космата мавпа", “Лісова пісня”, “Балядина”, “Хвесько Андибер”, “Адвокат Патлен” [21, арк. 1]. Тому припускаємо, що вибір цієї драматургії на сезон 1925-1926 рр. був не випадковим, а певним продовженням запланованих постановок для розвитку колективу. Тобто можемо констатувати, що незважаючи на складні умови функціонування, реорганізацію трупи, колектив театру імені Марії Заньковецької намагався продовжувати працювати стабільно, крок за кроком розвиваючи власну режисерську та акторську стилістику. Адже, як відомо, втілення драматургії творів В. Шекспіра $є$ добрим своєрідним мистецьким тренажем для випробування на професіональну зрілість театру.

Справді, театр імені Марії Заньковецької вів перемовини із Костянтином Станіславським щодо можливостей постановки на своїй сцені трагедії «Гамлет» В. Шекспіра [22, арк. 1]. Припускаємо, що посадовою особою, який вів ці перемовини від імені колективу, був саме директор театру Максим Лебідь, а не Борис Романицький, як припускають інші сучасні дослідники. Вважаємо, що М. Лебідь як директор театру був посвячений у творчі плани О. Корольчука щодо постановок творів Шекспіра на заньківчанській сцені. Відтак, після смерті О. Корольчука, М. Лебідь для налагодження подальшої послідовної і систематичної роботи театру імені Марії Заньковецької, задля уникнення можливої творчої кризи та використовуючи особисті дружні взаємини із керівництвом відділу мистецтв при Комісаріаті народної освіти, зокрема М. Христовим [23], спробував запросити для постановки «Гамлета» В. Шекспіра уславленого режисера К. Станіславського. А тому М. Лебідь спочатку вів листування із секретарем знаменитого режисера, сьогодні зберігся лише один такий лист [24, арк. 1].

Таким чином, із цього листування простежуємо, що перемовини заньківчан із К. Станіславським тривали впродовж певного часу. На жаль, лист колективу театру імені Марії Заньковецької до К. Станіславського не зберігся в архіві МХАТу. Проте у фондовій збірці Музею театрального, музичного і кіномистецтва України зберігається відповідь К. Станіславського заньківчанам щодо можливої постановки трагедії «Гамлет» [25, арк. 1]. Згодом цей лист був передрукований у 8-му томі праць К. Станіславського [26, 114]. Тобто постановці «Отелло» передувала спроба колективу 
зосередитися на постановці «Гамлета», яка виявилася невдалою. Слід, проте, зауважити, що Панас Саксаганський систематично виступав у трупі заньківчан у виставах за творами класичної драматургії у своїх коронних ролях. Як довідуємося iз листа О. Корольчука, навіть свій творчий ювілей П. Саксаганський святкував на заньківчанській сцені [27, арк.1-3].

На нашу думку, в контексті історії сценічного прочитання трагедії «Отелло» В. Шекспіра на сцені театру імені Марії Заньковецької в режисерській інтерпретації П. Саксаганського, слід також навести окремі штрихи про передумови виникнення цього спектаклю зі спогадів першого завідувача літературної частини заньківчан письменника Свгена Кротевича. Адже у спогадах драматурга Є. Кротевича знаходимо побіжну згадку про те, що під час кількох виступів у Полтаві до колективу приїхав Панас Саксаганський. [28, 124 139]. I під час цих короткотривалих гастрольних виступів автор спогадів зустрічався зі славетним актором у приватній обстановці [28, 124-125]. Отож Є. Кротевич мав можливість бачити, як знаменитий артист у своєму готельному номері репетирував роль Франца Моора із «Розбійників» Ф. Шіллера $[28,125]$. Також письменник відвідував артиста у його помешканні, адже на час полтавських гастролей вони мешкали поруч: «Якось сталося так, що його номер у полтавському готелі був поряд із номером, в якому мешкав я 3 дружиною, на тоді актрисою театру імені Марії Заньковецької. І щодня я бачився із Панасом Карповичем» $[28,125]$.

Також Євген Кротевич у своїх спогадах досить докладно описав, як Панас Саксаганський працював над своїми ролями. I в підсумку своїх спогадів зазначив таку показову деталь, яка «випала» 3 уваги практично всіх дослідників сценічних прочитань творів В. Шекспіра на заньківчанській сцені: «Часто Панас Карпович, коли я сидів у нього, читав напам'ять цілі монологи з шекспірівських п’єс. Великий артист Саксаганський так любив Шекспіра, що сам перекладав текст з російської на українську мову. Особливо любив він роль Фальстафа і шекспірівських блазнів взагалі. Але мені чомусь найчіткіше запам'ятався монолог у виконанні Саксаганського - можливо, через різкий контраст до комедійних образів» $[28,125]$. Тобто навіть у найскрутніший момент колектив заньківчан тією чи іншою мірою, наскільки це було можливо, намагався включити до свого репертуару шекспірівські твори. Отож назви «Гамлет» і «Отелло» В. Шекспіра в параграфі «План роботи» у «Намітках репертуару» 3'явилися не випадково і залучення Панаса Саксанського, вважаємо, також було для колективу досить органічним і послідовним.

Із здобуттям Україною незалежності фахове зацікавлення дослідників діяльністю театру імені Марії Заньковецької - саме 20-30-х рр. ХХ ст. знайшло своє відображення у концептуально новаторській монографії Н. Чечель «Театральне відродження. Західна класика на українській сцені 20-30-х рр.: проблеми трагедійної вистави» [29]. У своїй праці дослідниця проаналізувала режисерську концепцію та основні акторські образи цього спектаклю, спираючись, передовсім, на матеріали фондової збірки Музею театрального, музичного і кіномистецтва України: рукописи режисера П. Саксаганського, нотатки учасників вистави, а саме виконавців ролей: Брабанціо (Олесь Олесь), Яго (В. Яременко), Дездемони (Варвари Любарт), Отелло (Б. Романицького). Також Н. Чечель залучила до розгляду програмки та світлини цього спектаклю, перші телевізійні коментарі зазначених митців щодо їх участі у виставі «Отелло» В. Шекспіра [29, 35-56]. Отже це було хронологічно перше грунтовне дослідження з цієї теми в сучасному вітчизняному театрознавстві.

Крім того, нещодавно в Києві була в перекладі українською монографія канадської дослідниці українського походження I. Макарик «Перетворення Шекспіра: Лесь Курбас, український модернізм і радянська культурна політика 20-х років» [30]. У третьому розділі цієї монографії «Справжній Шекспір: “Отелло” Саксаганського» реконструюється здійснена Панасом Саксаганським постановка «Отелло» В. Шекспіра у 1925 р., але вже в контексті тогочасної культурної політики радянської влади [30, 147-177]. При цьому авторка аналізує цей матеріал у руслі постколоніальних методологічних стратегій, що надає особливої актуальності цій праці в царині історії вивчення перших сценічних прочитань драматургії Вільяма Шекспіра на українському кону [30, 11-16]. Оскільки ми не маємо на меті спеціально вивчати історію сценічних прочитань драматургії В. Шекспіра на заньківчанській сцені, то не будемо дублювати шлях, пройдений відомим істориком театру Іреною Макарик.

Також принагідно зауважимо, що заньківчанський спектакль «Отелло» В. Шекспіра, як зауважила у своїй монографії I. Макарик, зазнавав змін в акторській обсаді. Причому слід уточнити інформацію, наведену дослідницею: на світлинах вистави театру імені Марії Заньковецької «Отел- 
ло» В. Шекспіра у постановці П. Саксаганського справді відображені зміни у прізвищах артистів другорядних ролей [30, 308]. Адже після 1927 p., тобто після втрати стаціонарного приміщення у Катеринославі, цю постановку фактично зняли 3 активного репертуару колективу. В цей час із трупи вийшли учасники цього спектаклю: зокрема артистка Катерина Даценко, яка виконувала роль Емілії. А після стаціонування заьківчан у Запоріжжі у 1936 р. відбулося капітальне поновлення цього спектаклю режисером Василем Харченком, причому, як наголошувалося у пресі, концепція, стиль спектаклю залишилися саме Панаса Саксаганського [31, 268-276].

Крім того, заньківчани ще раніше на початку свого запорізького періоду здійснили ще одне важливе сценічне прочитання «Отелло» В. Шекспіра у режисерській інтерпретації І. Чабаненка, яке через «формалізм» було тривалий час затерте і фактично замовчуване в історії й заньківчанської та й національної шекспіріани зокрема $[32,302-$ 311]. Припускаємо, що у фондовій збірці Музею театрального музичного і кіномистецтва України у Києві не впорядковані світлини фактично трьох сценічних прочитань трагедії «Отелло» В. Шекспіра на сцені театру імені Марії Заньковецької: 1926, 1932 і 1936-го років відповідно. Тому виникають непорозуміння із підписами на фото у ілюстраціях до видань, присвячених діяльності заньківчан.

Окрім того, слід зазначити, що сьогодні в національному театрознавстві гостро відчутна актуальність вивчення і концептуального узагальнення режисерського доробку П. Саксаганського, а отже і його хронологічно останнього спектаклю як постановника [33, 239-240]. Адже монографія Л. Мельничук-Лучко «Панас Саксаганський актор», до того ж написана майже півстоліття тому, у радянський період навряд чи давала можливість вичерпно прокоментувати режисерську концепцію заньківчанського спектаклю «Отелло» В. Шекспіра у режисурі того ж таки П. Саксаганського [34]. Зрештою, як зазначив переконливо через півстоліття один із виконавців Яго у виставі «Отелло» Василь Яременко: «По суті, на сцені театру імені Марії Заньковецької було здійснено три сценічні редакції “Отелло”. Понад п'ятнадцять років ми пропагували цей великий твір. Я особисто зіграв трьох Яго - і всі вони різні» $[35,18]$.

Таким чином, можемо стверджувати, що заньківчанська постановка трагедії «Отелло» В. Шекспіра це водночас і важлива сторінка в історії національної шекспіріани, й важливий етап в історії діяльності самого колективу. Цей період функціонування театру ми окреслили як перехідний період, адже як державному колективові Головполітосвіта, після смерті О. Корольчука призначила заньківчанам іншого мистецького керівника, який мав прибути 3-за кордону, а саме Олександра Загарова. Але це вже інший, хоч і нетривалий, період в історії трупи.

\section{Джерела та література}

1. Яременко В. Десять років праці / Василь Яременко // Театр ім. Марії Заньковецької 1922-1932 ; [ред. кол. Б. Романицького, М. Фінна, В. Яременка, П. Руліна]. - Х. : ДВОУ «Мистецтво», 1933.

2. Наказ на удержавлення Державного драматичного театру імені заслуженої Народньої артистки Марії Заньковецької. - Центральний державний архів вищих органів влади та управління України (далі - ЦДАВОВУ України). - К. Ф. 166. - Спр. 593. - Арк. 24.

3. Романицький Б., Лебідь М. Лист до редакції! / Борис Романицький, Максим Лебідь // Вісті ВУЦВК. - Х., 1925. -21 березня. - № 64.

4. А. Театральная жизнь / А. // Красное Запорожье. - Запоріжжя, 1925. - 24 березня. - № 87.

5. Палій О. Репертуар прем'єр театру імені Марії Заньковецької (1921-1970) з архіву В. С. Яременка / Оксана Палій // Вісник Львівського університету. Серія мистецтвознавство. - Вип. 9. - Львів, 2009.

6. Лист Корольчука Олександра Івановича до Павла Андрійовича [прізвище особи не встановлено]. - Музей театрального, музичного і кіномистецтва України (далі МТМКУ). - Відділ рукописів. - Інв. № 9302. - Арк. 2.

7. Корольчук Олександр До Миколаївського відділу мистецтв при окрінспектурі при Наросвіти. - МТМКУ. - Відділ рукописів. - Інв. № 900с. - Арк. 1-3.

8. Письмо к А. И. Корольчуку от Николаевского отдела секции Робмис (Николаев, от 4 августа 1924 г.). - МТМКУ. Відділ рукописів - Інв. №1303 - Арк.1.

9. Посвідчення № 1542 театрові імені Марії Заньковецької. - ЦДАВОВУ України. - Ф. 166. - Од. зб. 593. - Арк. 4.

10. Лист Ізельсона до колективу театру ім. Заньковецької (Миколаїв, 17 листопада 1925). - ЦДАВОВУ України. Ф. 166. - Од. зб. 593. - Арк. 5.

11. Лебідь М. Державний драмтеатр ім. М. Заньковецької / М.[аксим] Лебідь // Зоря. - Катеринослав, 1925, травень. - № 5.

12. Щодо відомостей, які навів у цій публікації М. Лебідь про можливі відвідини Б. Романицьким виставки у Парижі, на наш погляд, слід зауважити таке: тогочасний художник театру імені Марії Заньковецької Андрій Іванович Таран у 1918-1922 р. навчався в Паризькій академії мистецтв у Анрі Матісса.

13. Після повернення в Україну, на запрошення О. І. Корольчука, з 1923-го по 1926 рр. А. І. Таран працював художником-постановником у заньківчанському колективі. За непідтвердженими відомостями у 1924 р. та 1926 р. під час роботи заньківчан на стаціонарі у Катеринославі, вистави театру імені Марії Заньковецької відвідало подружжя знаменитих французьких малярів Анрі Матісс та Лідія Делекторська. Такі відвідини могли бути реалізовані під час їхньої мандрівки з Парижа до Санкт-Петербурга. Відтак припускаємо, що запрошення на «виставку Паризьку», про яку згадував М. Лебідь у своїй публікації, напевно, було отримане керівництвом заньківчан під час відвідин митцями спектаклів трупи. 
14. Романицький Б., Яременко В. Сердечний привіт. (До початку гастролей Львівського державного театру імені М. Заньковецької) / Борис Романицький, Василь Яременко // Південна правда. - 1970. - 30 травня.

15. Заньківчани. Ілюстроване видання ; упоряд. М. Оверчук. - Львів, 1999.

16. Кордіані Б., Мельничук-Лучко Л. Театр імені М. Заньковецької / Б. Кордіані, Л. Мельничук-Лучко. - К. : Мистецтво, 1965. - 99 с.

17. Кулик О. Львівський театр імені М. К. Заньковецької / Олексій Кулик. - К. : Мистецтво, 1989. - 166 с. : іл.

18. Завадка Б. Борис Романицький / Б. Завадка. - К. : Мистецтво, 1978. - 144 с.

19. Мельничук-Лучко Л. Народна артистка / Л. Мельничук-Лучко. - Львів. : Каменяр, 1964. - 55 с.

20. Завадка Б., Турчин Ю. Василь Яременко / Б. Завадка, Ю. Турчин. - К. : Мистецтво, 1973. - 147 с.

21. Режисерські намітки Театру імені Марії Заньковецької на сезон 1923/1924 рр. Склав голова Ради театру Олександр Корольчук. - МТМКУ. - Відділ рукописів. - Інв. № 1646. - 3 арк.

22. Режисерські намітки Театру імені Марії Заньковецької на сезон 1924/1925 рр. Склав голова Ради театру Олександр Корольчук. - МТМКУ. - Відділ рукописів. - Інв. № 1648. - 3 арк.

23. Лист колективу театру імені Марії Заньковецької до Костянтина Станіславського (Катеринослав, 1925 р.) - МТМКУ. - Відділ рукописів. - Інв. № 44951 - 1 арк.

24. Яскравими свідченнями, на нашу думку, які підтверджують висловлену нами гіпотезу, є кілька збережених листів М. Лебідя до М. Христового, що нині зберігаються у фондовій збірці Центрального державного архіву вищих органів влади і управління України (Київ). Христовий Микола Федорович (1894-1938) - державний службовець. 31924 по 1929 рр. очолював відділ мистецтв при Народному комісаріаті освіти УРСР.

25. Лист секретаря К. Станіславського. - МТМКУ. - Відділ рукописів. - Інв. № 1619/67. -1 арк.

26. Лист колективу театру імені Марії Заньковецької до Костянтина Станіславського (Катеринослав, 1925 р.). МТМКУ. - Відділ рукописів. - Інв. № 44951. - 1 арк.

27. Станиславский К. С. Собрание сочинений : в 8 т. Письма 1918-1938 / К. С. Станиславский ; глав. ред. М. Н. Кедров. - М. : Искусство, 1961. - Т. 8. - Письмо № 84.

28. Корольчук Олександр. Лист до всього товариства. МТМКУ. - Відділ рукописів. - Особовий фонд Олександра Корольчука. - Інв. № 9418. - 3 арк.

29. Кротевич Є. Київські зустрічі. Спогади / Свген Кротевич. - К. : Мистецтво, 1965.

30. Чечель Н. Українське театральне відродження. (Західна класика на українській сцені 1920-1930-х років. Проблеми трагедійної вистави) / Н. Чечель. - К. : Мистецтво, 1993. - 144 c.

31. Макарик I. Перетворення Шекспіра : Лесь Курбас, український модернізм і радянська культурна політика 1920-х років / Ірина Макарик ; авториз. пер. М. Климчука. - К. : Ніка-Центр, 2010. - 348 с.

32. Палій О. Репертуарна афіша Театру імені Марії Заньковецької запорізького періоду (1931 -1941): постави за творами класичної драматургії / Оксана Палій // Записки Наукового Товариства ім. Шевченка. Праці театрознавчої комісії. - Львів, 2011. - Т. CCLXII.

33. Палій О. Заньківчанська шекспіріана запорізького періоду: до історії сценічних прочитань трагедії «Отелло» В. Шекспіра (1931-1941pp.) / Оксана Палій // Музейний вісник. Науково-теоретичний щорічник. - Запоріжжя, 2014. - №14.

34. Пилипчук Р. Життя і творчість Панаса Саксаганського в дослідженнях сучасних театрознавців / Ростислав Пили- пчук // Науковий вісник Київського національного університету театру, кіно і телебачення імені І. К. Карпенка-Карого, 2010. - Вип. 7.

35. Мельничук-Лучко Л. Панас Саксаганський - актор / Леонтина Мельничук-Лучко. - Львів. : Книжково-журнальне видавництво, 1958. - $252 \mathrm{c}$.

36. Яременко В. Згадую кілька вистав... / Василь Яременко // Український театр, 1972. - № 4. - Липень-серпень.

\section{References}

1. Iaremenko, V. (1993). Desiat rokiv pratsi // Teatr im. Marii Zankovetskoi 1922-1932 ; [red. kol. B. Romanytskoho, M. Finna, V. Yaremenka, P. Rulina]. - Kh. : DVOU «Mystetstvo» [in Ukrainian].

2. Nakaz na uderzhavlennia Derzhavnoho dramatychnoho teatru imeni zasluzhenoi Narodnoi artystky Marii Zankovetskoi. - Tsentralnyi derzhavnyi arkhiv vyshchykh orhaniv vlady ta upravlinnia Ukrainy (dali - TsDAVOVU). - K. - F. 166. - Spr. 593. - Ark. 24.

3. Romanytskyi, B., Lebid, M. (1925). Lyst do redaktsii! // Visti VUTsVK. - Kh., 21 bereznia. - № 64 [in Ukrainian].

4. A. Teatralnaia zhyzn (1925) // Krasnoe Zaporozhe. - Zaporizhzhia, 4 bereznia. - № 87 [in Russian].

5. Palii, O. (2009). Repertuar premier teatru imeni Marii Zankovetskoi (1921-1970) ; z arkhivu V. S. Yaremenka // Visnyk Lvivskoho universytetu. Seriia mystetstvoznavstvo. - Vyp. 9. - Lviv [in Ukrainian].

6. Lyst Korolchuka Oleksandra Ivanovycha do Pavla Andriiovycha [prizvyshche osoby ne vstanovleno]. - Muzei teatralnoho, muzychnoho i kinomystetstva Ukrainy (dali - MTMKU). - Viddil rukopysiv. - Inv. № 9302. - Ark. 2.

7. Korolchuk, Oleksandr. Do Mykolaivskoho viddilu mystetstv pry okrinspekturi pry Narosvity. - MTMKU. - Viddil rukopysiv. - Inv. № 900c. - Ark. 1-3.

8. Pysmo k A. Y. Korolchuku ot Nykolaevskoho otdela sektsyy Robmys (Nykolaev, ot 4 avhusta 1924 h.). - MTMKU. - Viddil rukopysiv - Inv. №1303 - Ark.1.

9. Posvidchennia № 1542 teatrovi imeni Marii Zankovetskoi. TsDAVOVU Ukrainy. - F. 166. - Od. zb. 593. - Ark. 4.

10. Lyst Izelsona do kolektyvu teatru im. Zankovetskoi (Mykolaiv, 17 lystopada 1925). - TsDAVOVU Ukrainy. - F. 166. Od. zb. 593. - Ark. 5.

11. Lebid, M. (1925). Derzhavnyi dramteatr im. M. Zankovetskoi // Zoria. - Katerynoslav, traven. - № 5 [in Ukrainian].

12. Shchodo vidomostei, yaki naviv u tsii publikatsii M. Lebid pro mozhlyvi vidvidyny B. Romanytskym vystavky u Paryzhi, na nash pohliad, slid zauvazhyty take: tohochasnyi khudozhnyk teatru imeni Marii Zankovetskoi Andrii Ivanovych Taran u 1918-1922 r. navchavsia v Paryzkii akademii mystetstv u Anri Matissa.

13. Pislia povernennia v Ukrainu, na zaproshennia O. I. Korolchuka, z 1923-ho po 1926 rr. A. I. Taran pratsiuvav khudozhnykom-postanovnykom u zankivchanskomu kolektyvi. Za nepidtverdzhenymy vidomostiamy u 1924 r. ta 1926 r. pid chas roboty zankivchan na statsionari u Katerynoslavi, vystavy teatru imeni Marii Zankovetskoi vidvidalo podruzhzhia znamenytykh frantsuzkykh maliariv Anri Matiss ta Lidiia Delektorska. Taki vidvidyny mohly buty realizovani pid chas yikhnoi mandrivky z Paryzha do Sankt-Peterburha. Vidtak prypuskaiemo, shcho zaproshennia na «vystavku Paryzku», pro yaku zghaduvav M. Lebid u svoii publikatsii, napevno, bulo otrymane kerivnytstvom zankivchan pid chas vidvidyn myttsiamy spektakliv trupy.

14. Romanytskyi, B., Yaremenko, V. (1970). Serdechnyi pryvit (Do pochatku hastrolei Lvivskoho derzhavnoho teatru imeni M. Zankovetskoi) // Pivdenna pravda, 30 travnia [in Ukrainian]. 
15. Zankivchany. Iliustrovane vydannia ; uporiad. M. Overchuk (1999). - Lviv [in Ukrainian].

16. Kordiani, B., Melnychuk-Luchko, L. (1965). Teatr imeni M. Zankovetskoi. - K. : Mystetstvo, 99 [in Ukrainian].

17. Kulyk, O. (1989). Lvivskyi teatr imeni M. K. Zankovetskoi.K. : Mystetstvo, 166 : il. [in Ukrainian].

18. Zavadka, B. (1978). Borys Romanytskyi. - K. : Mystetstvo, 144 [in Ukrainian].

19. Melnychuk-Luchko, L. (1964). Narodna artystka. - Lviv : Kameniar, 55 [in Ukrainian].

20. Zavadka, B., Turchyn, Yu. (1973). Vasyl Yaremenko. - K. : Mystetstvo, 147 [in Ukrainian].

21. Rezhyserski namitky Teatru imeni Marii Zankovetskoi na sezon 1923/1924 rr. Sklav holova Rady teatru Oleksandr Korolchuk. - MTMKU. - Viddil rukopysiv. - Inv. № 1646. 3 ark.

22. Rezhyserski namitky Teatru imeni Marii Zankovetskoi na sezon 1924/1925 rr. Sklav holova Rady teatru Oleksandr Korolchuk. - MTMKU. - Viddil rukopysiv. - Inv. № 1648. 3 ark.

23. Lyst kolektyvu teatru imeni Marii Zankovetskoi do Kostiantyna Stanislavskoho (Katerynoslav, 1925 r.) - MTMKU. Viddil rukopysiv. - Inv. № 44951 - 1 ark.

24. Iaskravymy svidchenniamy, na nashu dumku, yaki pidtverdzhuiut vyslovlenu namy hipotezu, ye kilka zberezhenykh lystiv M. Lebidia do M. Khrystovoho, shcho nyni zberihaiutsia u fondovii zbirtsi Tsentralnoho derzhavnoho arkhivu vyshchykh orhaniv vlady i upravlinnia Ukrainy (Kyiv) Khrystovyi Mykola Fedorovych (1894-1938) - derzhavnyi sluzhbovets. Z 1924 po 1929 rr. ocholiuvav viddil mystetstv pry Narodnomu komisariati osvity URSR.

25. Lyst sekretaria K. Stanislavskoho. - MTMKU. - Viddil rukopysiv. - Inv. № 1619/67. -1 ark.

26. Lyst kolektyvu teatru imeni Marii Zankovetskoi do Kostiantyna Stanislavskoho (Katerynoslav, 1925 r.). - MTMKU. Viddil rukopysiv. - Inv. №44951. - 1 ark.
27. Stanyslavskyi, K. S. (1961). Sobranye sochynenyi : v 8 t. Pysma 1918-1938; hlav. red. M. N. Kedrov. - M. : Yskusstvo. - T. 8. - Pysmo № 84.

28. Korolchuk, Oleksandr. Lyst do vsoho tovarystva. - MTMKU. - Viddil rukopysiv. - Osobovyi fond Oleksandra Korolchuka. - Inv. № 9418. - 3 ark.

29. Krotevych, Ye. (1965). Kyivski zustrichi. Spohady. - K. : Mystetstvo, 1965 [in Ukrainian].

30. Chechel, N. (1993). Ukrainske teatralne vidrodzhennia. (Zakhidna klasyka na ukrainskii stseni 1920-1930-kh rokiv. Problemy trahediinoi vystavy). - K. : Mystetstvo, 144 [in Ukrainian].

31. Makaryk, I. (2010). Peretvorennia Shekspira : Les Kurbas, ukrainskyi modernizm i radianska kulturna polityka 1920-kh rokiv; avtoryz. per. M. Klymchuka. - K. : Nika-Tsentr, 348 [in Ukrainian].

32. Palii, O. (2011). Repertuarna afisha Teatru imeni Marii Zankovetskoi zaporizkoho periodu (1931 -1941): postavy za tvoramy klasychnoi dramaturhii // Zapysky Naukovoho Tovarystva im. Shevchenka. Pratsi teatroznavchoi komisii. Lviv. - T. SSLKhII [in Ukrainian].

33. Palii, O. (2014). Zankivchanska shekspiriana zaporizkoho periodu: do istorii stsenichnykh prochytan trahedii «Otello» V. Shekspira (1931-1941rr.) // Muzeinyi visnyk. Naukovo-teoretychnyi shchorichnyk. - Zaporizhzhia. - №14 [in Ukrainian].

34. Pylypchuk, R. (2010). Zhyttia i tvorchist Panasa Saksahanskoho $\mathrm{v}$ doslidzhenniakh suchasnykh teatroznavtsiv // Naukovyi visnyk Kyivskoho natsionalnoho universytetu teatru, kino i telebachennia imeni I. K. Karpenka-Karoho. - Vyp. 7 [in Ukrainian].

35. Melnychuk-Luchko, L. (1958). Panas Saksahanskyi aktor. - Lviv : Knyzhkovo-zhurnalne vydavnytstvo, 252 [in Ukrainian].

36. Yaremenko, V. (1972). Zghaduiu kilka vystav... // Ukrainskyi teatr. - № 4. - Lypen-serpen. [in Ukrainian]. 